\title{
Microwave and convective air on drying of araucaria angustifolia seeds
}

\section{Utilização de micro-ondas e ar quente na secagem de sementes de araucaria angustifolia}

\author{
Naiara Nobre dos Reis ${ }^{1 *}$; Joyce Yumi Taira1; Leda Battestin Quast²; Ernesto Quast²; \\ Antonio Marsaioli Junior ${ }^{3}$; Bruna da Silva Garais ${ }^{4}$
}

\section{Highlights}

Potential use of microwaves to dry Araucaria angustifolia seeds.

Influence of microwave power on drying temperature and time.

Variation of phenolic compounds in drying processes.

\begin{abstract}
Microwave drying has shorter processing times compared with convection drying, which results in highquality products and reduced energy consumption. The objective of this study is to evaluate the drying process of Araucaria angustifolia seeds using hot air at atmospheric pressure by applying microwaves (300 $\mathrm{W}$ and $500 \mathrm{~W})$, and comparing them with the conventional drying process using hot air $\left(80^{\circ} \mathrm{C}\right)$. The drying time using hot air with microwaves at $500 \mathrm{~W}$ and $300 \mathrm{~W}$ was reduced by $83.33 \%$ and $73.89 \%$, respectively, compared with conventional drying. The drying process occurred in the transient regime, with the predominance of a period of decreasing drying rate. The internal temperature of Araucaria seeds increased with the exposure time to the drying process, whereas the moisture content decreased. This tendency was greater for seeds subjected to electromagnetic fields, especially those exposed to higher power. The total phenolic compounds (TPCs) were lower by microwave drying when compared with conventional drying. The TPC loss was influenced by the internal temperature of the seed. Alternative methods to promote the increased retention of phenolic compounds during the drying process include decreasing the microwave power before the end of drying, combining traditional microwave-associated drying methods, and controlling the applied microwave power.
\end{abstract}

Key words: Phenolic compounds. Power. Process. Seed.

1 Students of the Undergraduate Course in Food Engineering, Federal University of Fronteira Sul, UFFS, Laranjeiras do Sul, PR, Brazil. E-mail: naiarareis.nobre@gmail.com; tairajoyce@gmail.com

2 Profs., Department of Food Engineering, UFFS, Laranjeiras do Sul, PR, Brazil. E-mail: leda.quast@uffs.edu.br; ernesto. quast@uffs.edu.br

3 Researcher, Food Technology Institute, ITAL, Campinas, SP, Brazil. E-mail: tonymars@uol.com.br

${ }^{4}$ Student of the Master's Course in Food Science and Technology, UFFS, Laranjeiras do Sul, PR, Brazil. E-mail: brunagarais@gmail.com

* Author for correspondence

Received: Aug. 26, 2020 - Approved: Feb. 09, 2021 


\section{Resumo}

Comparados aos secadores por convecção, os secadores dielétricos têm tempos de secagem mais curtos, proporcionando produtos de melhor qualidade e consequentemente menor consumo de energia. $\mathrm{O}$ objetivo deste estudo foi avaliar os processos de secagem de sementes de Araucaria angustifolia usando ar quente à pressão atmosférica, aplicando micro-ondas (300 W e $500 \mathrm{~W}$ ) e compará-los ao processo de secagem convencional com ar quente $\left(80^{\circ} \mathrm{C}\right)$. $\mathrm{O}$ tempo de processo de secagem usando ar quente com micro-ondas foi reduzido em 83,33\% na potência de 500 W e 73,89\% a 300 W, quando comparado à secagem convencional. Os processos de secagem ocorreram no regime transiente, com predominância do período de taxa decrescente. Observou-se que os valores da temperatura interna aumentaram com o tempo de exposição do material ao processo, enquanto a umidade diminuiu. Essa tendência foi maior para sementes submetidas a campos eletromagnéticos, principalmente aquelas expostas a maior potência. Os compostos fenólicos totais foram menores na secagem por micro-ondas quando comparados à secagem convencional. A perda de compostos fenólicos foi influenciada pela temperatura no interior do produto. As alternativas para promover maior retenção de compostos fenólicos no processo de secagem seriam a diminuição da potência antes do final da secagem, a combinação dos métodos tradicionais de secagem associados às micro-ondas e o controle da potência a ser aplicada no micro-ondas.

Palavras-chave: Compostos fenólicos. Potência. Processo. Sementes.

\section{Introduction}

Araucaria angustifolia is a gymnosperm with pine cones formed by approximately 100 seeds, known as pine nuts. Its peel is red and has an edible pulp that is too hard to consume in natura. As a result, the seeds must be processed to soften their texture prior to consumption (Zortéa-Guidolin, Carvalho, Godoy, Demiate, \& Scheer, 2017; Quinteiro, Alexandre, \& Magalhães, 2019).

Phenolic compounds are substances with free and complex structures that exhibit antioxidant properties. These structures are found in fruits and vegetables, and provide health benefits, such as the prevention of cancer and cardiovascular disease (Angelo \& Jorge, 2007; Cataneo, Caliari, Gonzaga, Kuskoski, \& Fett, 2008; Liu, 2013). Several studies on fruits have reported the effect of drying temperature on phenolic compounds, i.e., an increase in their degradation with the increase in temperature (Garcia-Perez, GarcíaAlvarado, Carcel, \& Mulet, 2010; Suvarnakuta, Chaweerungrat, \& Devahastin, 2011; Djendoubi, Boudhrioua, Kechaou, Courtois, \& Bonazzi, 2012; Karaaslan et al., 2014).

Phenolic compounds found in Araucaria seeds include procyanidins (catechin and epicatechin derivatives), phenolic acids (protocatechuic acid and ferulic acid hexoside), and flavonoids (Koehnlein et al., 2012; Santos et al., 2018). According to Cordenunsi et al. (2004) and Koehnlein et al. (2012), when Araucaria seeds (pine nuts) are cooked, the amount of phenolic compounds increase because of their migration from husk to the seed during cooking. 
The pine nut is a seasonal product native to southern Brazil, where it is highly appreciated and frequently sold in informal markets. The Araucaria seed has high moisture levels and water activity; hence, it is easily contaminated by microorganisms during storage, which hinders its commercialization (Cladera-Olivera, Pettermann, Noreña, Wada, \& Marczak, 2008). The development of new food products from Araucaria seeds can provide an alternative method of commercialization during the off-season at an increased value. Drying is one of the main methods of food preservation. However, the high temperatures and long drying times in conventional drying can damage the food, changing its texture, color, taste, and nutritional value. Microwave drying can reduce such damage (Menon, Stojceska, \& Tassou, 2020).

Microwave drying of foods with high moisture content is an efficient method. In conventional drying, heat transfer occurs because of the temperature gradient between the dry surface and the humid center, making it longer to complete the process. On the other hand, microwaves can penetrate the food and heat it because of the interaction between the electromagnetic field and dipolar molecules, especially water molecules, causing an instantaneous rise in internal temperature and shorter drying times (Béttega, Rosa, Corrêa, \& Freire, 2014).

A literature review has shown that several studies have been conducted on microwave drying. The studies are related to the production of husked cherry coffee (Cunha, Canto, \& Marsaioli, 2003), coconut husk (Valadez-Carmona, Cortez-García, PlazolaJacinto, Necoechea-Mondrágon, \& Ortiz-
Moreno, 2016), dried carrots (Béttega et al., 2014), strawberries (Böhm, Kühnert, Rohm, \& Scholze, 2006), macadamia nuts (Silva, Maximo, Marsaioli, \& Silva, 2007), and granulated solids (Berteli, Nogueira, \& Marsaioli, 2015). However, there is a lack of studies on the microwave drying of Araucaria seeds. Many studies in the literature also exhibit an information gap and a lack of data accuracy, assuming that several studies have been performed using adapted domestic microwaves.

The objective of this study is to evaluate the use of microwaves to dry Araucaria angustifolia seeds, their behavior during drying, and the total phenolic compounds (TPC) after processing.

\section{Materials and Methods}

\section{Sampling}

Araucaria angustifolia seeds (pine nuts) were purchased from a local market in Pinhão, Paraná, Brazil. Samples were preselected to exclude germinated seeds and seeds that were mechanically damaged or attacked by insects or fungi. The selected samples were stored in sealed plastic bags at $-21^{\circ} \mathrm{C}$ until further use.

\section{Cooking process}

The cooking process was carried out in batches of $200 \mathrm{~g}$ of pine nuts in $2 \mathrm{~L}$ of potable water in a pressure cooker at $2.5 \mathrm{~atm}$ for 30 min. The cooked seeds were peeled and cut in half longitudinally. Afterward, the samples were identified and subjected to the drying process. 
Centesimal characterization of in natura and cooked Araucaria seeds

According to the methodologies described in the literature (Instituto Adolfo Lutz [IAL], 1986), pine nuts were characterized by their moisture, protein, ash, and lipid content. Characterization was performed for in natura and cooked seeds. All analyses were conducted at least three times.

\section{Drying}

Drying tests were performed on the cooked and peeled Araucaria seeds. In microwave drying, the air temperature was $59^{\circ} \mathrm{C}$ at $300 \mathrm{~W}$ and $500 \mathrm{~W}$. In the conventional (CONV80) drying process with circulation and forced air renewal, the velocity was $1 \mathrm{~m} \mathrm{~s}^{-1}$ at $80{ }^{\circ} \mathrm{C}$. The mass of Araucaria seeds used in each experiment was $200 \pm 3.91 \mathrm{~g}$. During the drying process, the internal temperature of the seeds was monitored using thermocouples. For conventional drying, the experiments were performed in triplicate. For microwave drying, experiments were conducted with one sample owing to cell size limitations. Before the tests, the microwave drying system was experimentally validated. The experiments were conducted in a multifunctional pilot plant designed for the application of microwaves in food processing at the Engineering and Post-harvest Group of the Institute of Food Technology.

Based on previous tests, a moisture content of approximately $20 \%$ (wet basis) was established as the endpoint parameter of the microwave drying process. This value was determined based on the texture characteristics, considering the possibility of dry seed consumption as chips or its use as a raw material in food product formulations.

After drying, the seeds were labeled and stored under vacuum in low-density nylon/ polyethylene transparent bags.

Extraction and determination of total phenolic compounds

The extracts were obtained using the methodology described by Santos et al. (2018), with some modifications. Cooked and ground Araucaria seeds $(2.5 \mathrm{~g})$ were solubilized in 100 $\mathrm{mL}$ of $45 \%\left(\mathrm{v} \mathrm{v}^{-1}\right)$ ethanol and stirred at 780 rpm for $1 \mathrm{~h}$ and $10 \mathrm{~min}$ at $63.5^{\circ} \mathrm{C}$. The extracts were filtered and stored at $-20^{\circ} \mathrm{C}$ until phenolic analysis.

The TPCs were determined using the Folin-Ciocalteau method (Bucić-Kojić, Planinić, Tomas, Bilić, \& Velić, 2007). The extract (1 mL), Folin-Ciocalteu reagent at $10 \%\left(\mathrm{v} \mathrm{v}^{-1}\right)(4 \mathrm{~mL})$, and sodium carbonate solution at $7.50 \%(\mathrm{~m}$ $\left.\mathrm{v}^{-1}\right)(2 \mathrm{~mL})$ were placed in a $25 \mathrm{~mL}$ flask and filled with distilled water. After homogenization and storage ( $2 \mathrm{~h}$ in the absence of light), the absorbance was measured at $765 \mathrm{~nm}$. The standard curve was constructed using gallic acid (AG) at $0.2,0.5,1.0$, and $2.5 \mathrm{mg} \mathrm{AG} \mathrm{L}^{-1}$. The results are expressed in mg AG $100-1 \mathrm{~g}^{-1}$ of the dry sample. The analyses were performed in triplicate.

\section{Statistical analysis}

The results were evaluated using the analysis of variance and Tukey's test with a $95 \%$ confidence level. 


\section{Results and Discussion}

The proximate analysis of in natura and cooked Araucaria seeds (Table 1) showed that the moisture content of in natura seeds was $46.24 \%$, similar to those reported in the literature (Cordenunsi et al., 2004; Gama, Masson, Haracemiv, Zanette, \& Córdova,
2010), whose values were close to $50 \%$. The cooked seeds in the present study contained $50.67 \%$ moisture, similar to that found (Capella, Penteado, \& Balbi, 2009). This increase in moisture during cooking $(p<0.05)$ is attributed to the absorption of water by the seed, which changes in its physical and sensory structure.

Table 1

Results of centesimal analysis of in natura and cooked Araucaria seeds

\begin{tabular}{|ccccc|}
\hline Parameters & In natura seeds & Cooked seeds & F-calc & p-value \\
\hline Moisture \% (wb) & $46.24 \pm 0.44$ & $50.67 \pm 0.67$ & 214.11 & 0.009 \\
\hline Ash \% (db) & $2.37 \pm 0.02$ & $2.58 \pm 0.02$ & 1.41 & 0.829 \\
\hline Proteins \% (db) & $6.88 \pm 0.18$ & $6.81 \pm 0.16$ & 1.26 & 0.884 \\
\hline Lipids \% (db) & $2.08 \pm 0.14$ & $2.28 \pm 0.03$ & 24.99 & 0.077 \\
\hline
\end{tabular}

wb (wet basis) and db (dry basis). Results are expressed as mean \pm standard deviation. Fisher calculated test at 95\% confidence level.

With regard to the ash, protein, and lipid content, the results for in natura and cooked seeds were similar, indicating that the cooking process did not significantly affect these physicochemical characteristics ( $p>0.05)$. The values for in natura and cooked seeds obtained in this study are close to those reported in the literature (Zortéa-Guidolin et al., 2017; Capella et al., 2009; Cladera-Olivera et al., 2008).

Considering the drying process (Figure 1), it can be observed that the samples did not reach their equilibrium moisture content because this condition was not required in the process. The endpoint for the microwavetreated samples was a final moisture content of approximately $20 \%(\mathrm{wb})$, which corresponds to a moisture of $0.25 \mathrm{~g} \mathrm{H}_{2} \mathrm{O} \mathrm{g}^{-1}(\mathrm{db})$. Figure 1 shows that for the microwave process, the drying time was reduced by $83.33 \%$ and $73.89 \%$ at $500 \mathrm{~W}$ and $300 \mathrm{~W}$, respectively, compared with conventional drying. After $3 \mathrm{~h}$, conventional drying resulted in a final moisture content of $28.30 \%$ (wb), which corresponds to $0.3947 \mathrm{~g} \mathrm{H}_{2} \mathrm{O} \mathrm{g}^{-1}(\mathrm{db})$. The water loss of the Araucaria seeds subjected to microwave drying was faster than that in the conventional system. In this last case, the exposure time of the seed to heat was longer compared with the other methods. 


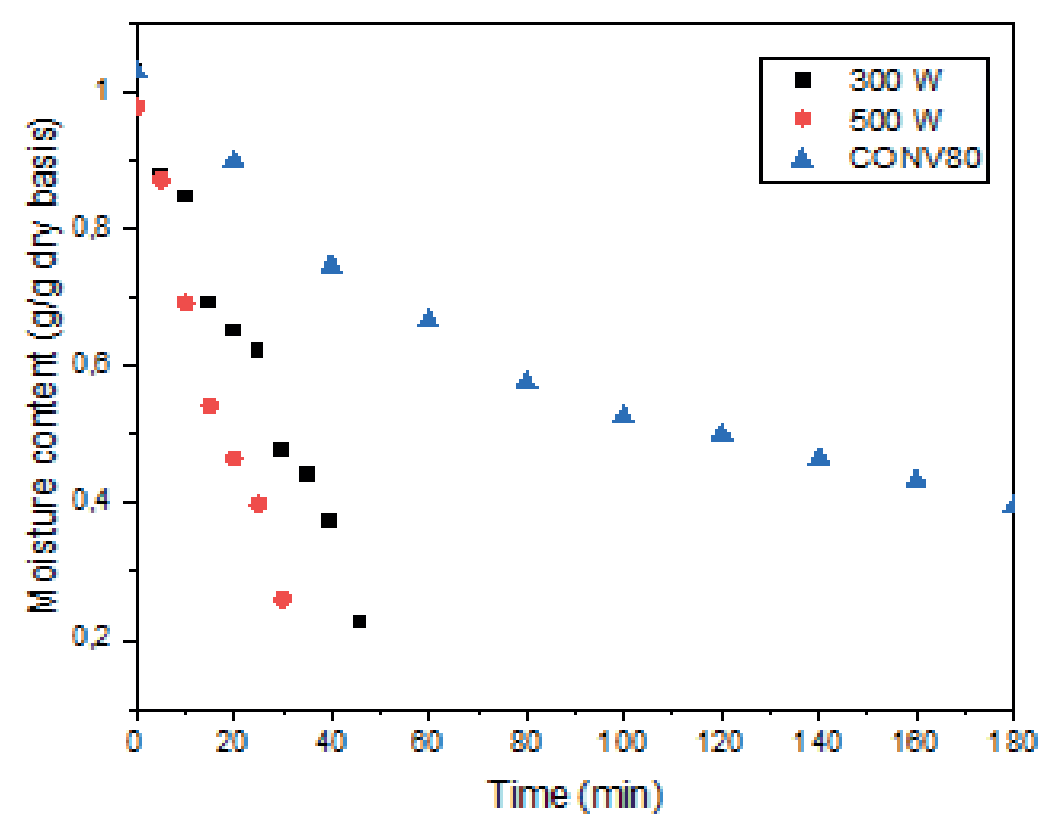

Figure 1. Drying kinetics for peeled cooked seeds while drying under different treatments. $300 \mathrm{~W}=$ microwaves applied at $300 \mathrm{~W} ; 500 \mathrm{~W}=$ microwaves applied at $500 \mathrm{~W} ; \mathrm{CONV80}=$ conventional drying process with hot air at $80^{\circ} \mathrm{C}$.

A mathematical analysis was performed on the drying kinetics (Table 2), following the first derivative obtained to obtain the drying rate data (Figure 2).

Table 2

Drying models and their derivatives estimated for mathematical adjustment

\begin{tabular}{cccc} 
Treatment & Mathematical adjustment & $\begin{array}{c}\text { Determination } \\
\text { Coefficient- } R^{2}\end{array}$ & Derivative \\
\hline $300 W$ & $Y=3 E-05 x^{2}-0.0176 x+0.9972$ & 0.9836 & $Y=6 E-05 x-0.0176$ \\
$500 W$ & $Y=3 E-04 x^{2}-0.0317 x+0.9898$ & 0.9905 & $y=6 E-04 x-0.0317$ \\
CONV80 & $y=2 E-05 x^{2}-0.0068 x+1.0148$ & 0.9918 & $y=4 E-05 x-0.0068$
\end{tabular}

$300 \mathrm{~W}=$ applying microwaves at $300 \mathrm{~W} ; 500 \mathrm{~W}=$ applying microwaves at $500 \mathrm{~W} ; \mathrm{CONV} 80=$ conventional drying process with hot air at $80^{\circ} \mathrm{C}$. 


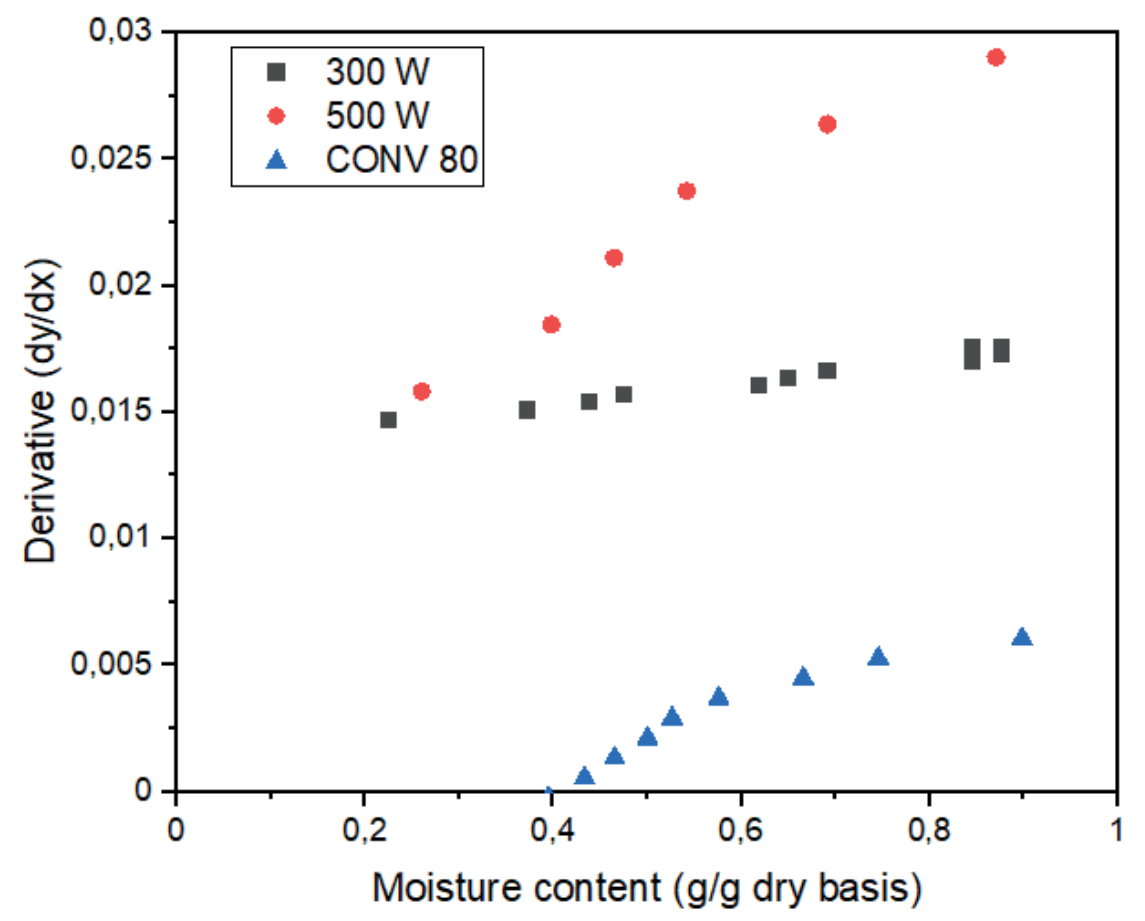

Figure 2. Drying rate curves.

$300 \mathrm{~W}=$ microwaves applied at $300 \mathrm{~W} ; 500 \mathrm{~W}=$ microwaves applied at $500 \mathrm{~W} ; \operatorname{CONV80}=$ conventional drying process with hot air at $80^{\circ} \mathrm{C}$.

The adjustment followed a secondorder polynomial, whose determination coefficients were greater than 0.9800 .

The drying rate curves (Figure 2) show that conventional drying caused the smallest variations in the dying rate; the final moisture content was higher than those at $300 \mathrm{~W}$ and 500 W. Graphically, the prevalence of the decreasing rate was observed, which indicates that drying occurs in the transient regime, where the mass transfer is driven by internal diffusion (Nascimento, Biagi, \& Oliveira, 2015; Resende, Ullmann, Siqueira, Chaves, \& Ferreira, 2011).

Monitoring of internal temperature profile of the seeds during the drying process (Figure 3 ) showed that the internal temperatures varied for each treatment.
In conventional drying, the seeds were subjected to an internal temperature of 60.87 ${ }^{\circ} \mathrm{C}$. In microwave drying at $500 \mathrm{~W}$, the internal temperature reached $97.58^{\circ} \mathrm{C}$. According to Martins, Melo, Barbosa, Santos and Machado (2002), higher temperatures led to a shorter processing time, but resulted in greater nutrient losses and structural changes in the seed. Drying at $500 \mathrm{~W}$ can be advantageous in terms of processing time and cost, but it can cause undesirable product modifications that must be investigated.

Conventional drying provides a mild internal temperature compared with other processes; however, the heat exposure time is much longer, which can also cause significant nutritional losses This fact was confirmed by Soares, Chaves, Silva, Silva and Souza (2007), 
who studied the drying of basil at different temperatures. They found that using a lower temperature increased the processing time as well as the loss of chemical compounds. At $300 \mathrm{~W}$, the internal temperature of the seed reached a maximum of $69.05{ }^{\circ} \mathrm{C}$, which is $8.18^{\circ} \mathrm{C}$ higher than the temperature reached by the seed in conventional drying; however, the drying time was approximately four times shorter.

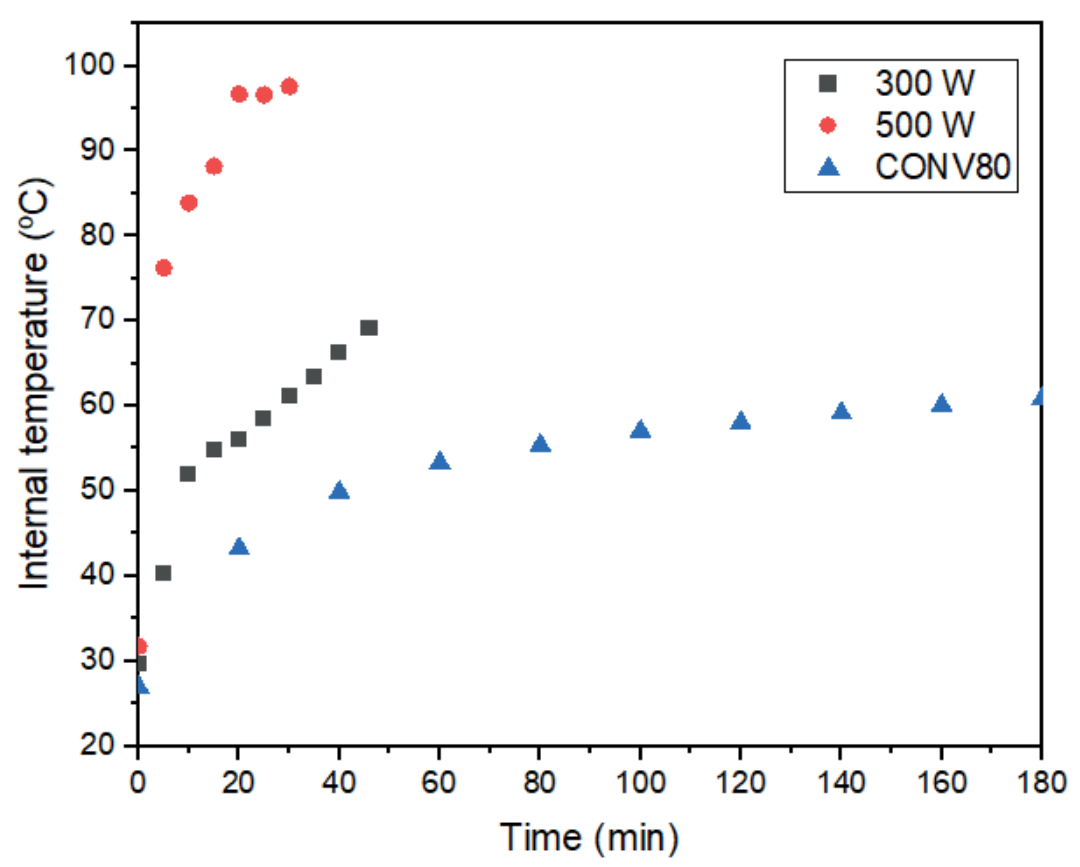

Figure 3. Internal temperature of the peeled cooked seeds while drying under different treatments. $300 \mathrm{~W}=$ microwaves applied at $300 \mathrm{~W} ; 500 \mathrm{~W}=$ microwaves applied at $500 \mathrm{~W} ; \mathrm{CONV} 80=$ conventional drying process with hot air at $80^{\circ} \mathrm{C}$.

During the drying process, the internal temperature of the seed subjected to 500 $\mathrm{W}$ increased rapidly in the first 20 min, after which it exhibited a more asymptotic behavior. This may be because the dielectric properties of the seed lost their capacity for microwave absorption during processing at high temperatures, causing temperature stability.

It was observed that the temperature increased with the exposure time of the seed to the process, while the moisture content decreased. This tendency was greater for seeds subjected to electromagnetic fields, especially those exposed to higher power.
The TPCs in Araucaria seeds (Table 3) significantly decreased ( $p<0.05$ ) during the drying process. The seeds subjected to microwave drying showed higher TPC losses

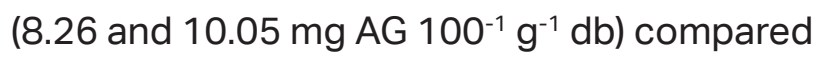
with conventional drying (16.63 mg AG 100-1 $\mathrm{g}^{-1} \mathrm{db}$ ). In conventional drying, the exposure time was long ( $3 \mathrm{~h})$, but the seed's internal temperature was low $\left(60.87^{\circ} \mathrm{C}\right)$. In microwave drying at 300 and $500 \mathrm{~W}$, the seed's maximum internal temperatures were $69.05{ }^{\circ} \mathrm{C}$ and $97.58{ }^{\circ} \mathrm{C}$, respectively. This result showed that TPC loss was influenced by the internal temperature of the seed. 
Table 3

TPCs for different treatments

\begin{tabular}{|cc|}
\hline Treatments & TPC $\left(\mathrm{mg} \mathrm{AG} 100^{-1} \mathrm{~g}^{-1} \mathrm{db}\right)^{*}$ \\
\hline Cooked before drying & $19.46 \pm 0.35 \mathrm{a}$ \\
CONV80 & $16.63 \pm 0.57 \mathrm{~b}$ \\
$300 \mathrm{~W}$ & $8.26 \pm 0.14 \mathrm{~d}$ \\
$500 \mathrm{~W}$ & $10.05 \pm 0.13 \mathrm{c}$
\end{tabular}

Different letters in the column indicate significant differences $(p<0.05)$ according to Tukey's test.

$300 \mathrm{~W}=$ applying microwaves at $300 \mathrm{~W} ; 500 \mathrm{~W}=$ applying microwaves at $500 \mathrm{~W} ; \mathrm{CONV} 80=$ conventional drying process with hot air at $80^{\circ} \mathrm{C}$.

Alternative methods to promote the retention of phenolic compounds during the drying process include decreasing the microwave power before the end of drying (Wojdyło, Figiel, Lech, Nowicka, \& Oszmiański, 2014), combining traditional microwaveassociated drying methods (Samoticha, Wojdylo, \& Lech, 2016), and varying the microwave power used (Coklar, Akbulut, Kilinc, Yildirim, \& Alhassan, 2018). In addition, it is necessary to evaluate the physicochemical and functional characteristics of food to establish adequate processing conditions, costs, and product quality.

\section{Conclusion}

Microwave drying can be used as an alternative method for drying Araucaria seeds. The drying time was shorter for seeds subjected to microwave dying compared with the conventional process. The TPCs were lower in microwave drying than in conventional drying, indicating that temperature influenced this process.

\section{Acknowledgments}

ITAL (Food Technology Institute) and UFFS (Federal University of Fronteira Sul).

\section{References}

Angelo, P. M., \& Jorge, N. (2007). Compostos fenólicos em alimentos - uma breve revisão. Revista do Instituto Adolfo Lutz, 66(1), 1-9.

Berteli, M., Nogueira, T. L., \& Marsaioli, A., Jr. (2015). Determination of the 6temperature distributions in a paddy rice bed. Brazilian Journal of Food Technology, 17(4), 319328. doi: 10.1590/1981-6723.4814

Béttega, R., Rosa, J. G., Corrêa, R. G., \& Freire, J. T. (2014). Comparison of carrot (Daucus carota) drying in microwave and in vacuum microwave. Brazilian Journal of Chemical Engineering, $31(2)$, 403-412. doi: 10.1590/0104$6632.20140312 s 00002668$

Böhm, V., Kühnert, S., Rohm, H., \& Scholze, G. (2006). Improving the nutritional quality of microwave-vacuum dried strawberries: 
A preliminary study. Food Science and Technology International, 12(1), 67-75. doi: $10.1177 / 1082013206062136$

Bucić-Kojić, A., Planinić, M., Tomas, S., Bilić, M., \& Velić, D. (2007). Study of solid-liquid extraction kinetics of total polyphenols from grape seeds. Journal of Food Engineering, 81(1), 236-242. doi: 10. 1016/j.jfoodeng.2006.10.027

Capella, A. C. V., Penteado, P. T. P. S., \& Balbi, M. E. (2009). Semente de Araucaria angustifolia: aspectos morfológicos e composição química da farinha. Boletim Centro de Pesquisa de Processamento de Alimentos, 27(1), 135-142. doi: 10.5380/ cep.v27i1.15009

Cataneo, C. B., Caliari, V., Gonzaga, L. V., Kuskoski, E. M., \& Fett, R. (2008). Atividade antioxidanteeconteúdofenólicodoresíduo agroindustrial da produção de vinho. Semina: Ciências Agrárias, 29(1), 93-102. doi: 10.5433/1679-0359.2008v29n1p93

Cladera-Olivera, F., Pettermann, A. C., Noreña, C., Wada, K., \& Marczak, L. D. F. (2008). Thermodynamic properties of moisture desorption of raw pinhão (Araucaria angustifolia seeds). International Journal of Food Science \& Technology, 43(5), 900-907. doi: 10.1111/j.1365-2621.2007. 01540.x

Coklar, H., Akbulut, M., Kilinc, S., Yildirim, A., \& Alhassan, I. (2018). Effect of freeze, oven and microwave pretreated oven drying on color, browning index, phenolic compounds and antioxidant activity of hawthorn (Crataegus orientalis) fruit. Notulae Botanicae Horti Agrobotanici ClujNapoca, 46(2), 449-456. doi: 10.15835/ nbha46211027
Cordenunsi, B. R., Menezes, E. W., Genovese, M. I., Colli, C., Gonçalves de Souza, A., \& Lajolo, F. M. (2004). Chemical composition and glycemic index of Brazilian pine (Araucaria angustifolia) seeds. Journal of Agricultural and Food Chemistry, 52(11), 3412-3416. doi: 10.1021/jf034814l

Cunha, M. L., Canto, M. W., \& Marsaioli, A., Jr. (2003). Secagem de café cereja descascado por ar quente e microondas. Ciência e Tecnologia de Alimentos, 23(3), 381-385. doi: 10.1590/s0101-206120030 00300015

Djendoubi, N. M., Boudhrioua, N., Kechaou, N., Courtois, F., \& Bonazzi, C. (2012). Influence of air drying temperature on kinetics, physicochemical properties, total phenolic content and ascorbic acid of pears. Food and Bioproducts Processing, 90(3), 433441. doi: 10.1016/j.fbp.2011.11.009

Gama, T. M. M. T. B., Masson, M. L., Haracemiv, S. M. C., Zanette, F., \& Córdova, K. R. V. (2010). A influência de tratamentos térmicos no teor de amido, colorimetria e microscopia de pinhão nativo (Araucaria angustifolia) e pinhão proveniente de polinização controlada. Revista Brasileira de Tecnologia Agroindustrial, 4(2), 161178. doi: 10.3895/s1981-36862010000 200005

Garcia-Perez, J. V., García-Alvarado, M. A., Carcel, J. A., \& Mulet, A. (2010). Extraction kinetics modeling of antioxidants from grape stalk (Vitis vinifera var. Bobal): Influence of drying conditions. Journal of Food Engineering, 101(1), 49-58. doi: 10.1016/j.jfoodeng.2010.06.008

Instituto Adolfo Lutz (1986). Métodos químicos e físicos para análise de alimentos. São Paulo, SP: Instituto Adolfo Lutz. 
Karaaslan, M., Yilmaz, F. M., Ozge, C., Vardin, H., Ikinci, A., \& Dalgic, A. C. (2014). Drying kinetics and thermal degradation of phenolic compounds and anthocyanins in pomegranate arils dried under vacuum conditions. International Journal of Food Science \& Technology, 49(2), 595-605. doi: 10.1111/ijfs.12342

Koehnlein, E. A., Carvajal, A. E. S., Koehnlein, E. M., Coelho-Moreira, J. S., Inácio, F. D., Castoldi, R.,... Peralta, R. M. (2012). Antioxidant activities and phenolic compounds in raw and cooked Brazilian pinão (Araucaria angustifolia seeds). African Journal of Food Science, 6(21), 512-518. doi: 10.5897/AJFS12.128

Liu, R. H. (2013). Dietary bioactive compounds and their health implications. Journal of Food Science, 78(1), 18-25. doi: 10.1111/1750-3841.12101

Martins, P. M., Melo, E. C., Barbosa, L. C. A. B., Santos, R. H. S., \& Machado, M. C. (2002). Influência da temperatura e velocidade do ar de secagem no teor e composição química do óleo essencial de capim-limão. Acta Horticulturae, 569, 155-160. doi: 10.17660/ActaHortic.2002.569.25

Menon, A., Stojceska, V., \& Tassou, S. A. (2020). A systematic review of recent advances of the energy efficiency improvements in non-conventional food drying technologies. Trends in Food Science \& Technology, 100, 67-76. doi: 10.17660/ ActaHortic.2002.569.25

Nascimento, V. R. G., Biagi, J. D., \& Oliveira, R. A. (2015). Modelagem matemática da secagem convectiva com radiação infravermelha de grãos de Moringa oleífera. Revista Brasileira de Engenharia
Agrícola e Ambiental, 19(7), 686-692. doi: 10.1590/1807-1929/agriambi.v19n7 p686-692

Quinteiro, M. M. da C., Alexandre, B. R., \& Magalhães, L. M. S. (2019). Brazilian pine (Araucaria angustifolia Bertol.) Kuntze) ethnoecology in the Mantiqueira Atlantic Forest. Floresta and Ambiente, 26(1), 1-7. doi: 10.1590/2179-8087.018516

Resende, O., Ullmann, R., Siqueira, V. C., Chaves, T. H., \& Ferreira, L. U. (2011). Modelagem matemática e difusividade efetiva das sementes de pinhão-manso (Jatropha curcas L.) durante a secagem. Engenharia Agricola, 31(6), 1123-1135. doi: 10.1590/ s0100-69162011000600010

Samoticha, J., Wojdyło, A., \& Lech, K. (2016). Influence of different drying methods on Iz composition and antioxidant activity in chokeberries. LWT - Food Science and Technology, 66, 484-489. doi: 10.1016/j. Iwt.2015.10.073

Santos, C. H., Baqueta, M., Coqueiro, A., Dias, M., Barros, L., Barreiro, M.,... Leimann, F. (2018). A systematic study on the extraction of antioxidants from Pinhão (Araucaria angustifolia (Bertol.) Kuntze) coat. Food Chemistry, 261, 216-223. doi: 10.1016/j.foodchem.2018.04.057

Silva, F. A., Maximo, G. J., Marsaioli, A., \& Silva, M. A. A. P. (2007). Impacto da secagem com microondas sobre o perfil sensorial de amêndoas de noz macadâmia. Ciencia e Tecnologia de Alimentos, 27(3), 553561. doi: 10.1590/S0101-206120070003 00020

Soares, R. D., Chaves, M. A., Silva, A. A. L. da, Silva, M. V. da, \& Souza, B. dos S. (2007). Influência da temperatura e velocidade do 
ar na secagem de manjericão (Ocimum basilicum L.) com relação aos teores de óleos essenciais e de linalol. Ciência e Agrotecnologia, 31(4), 1108-1113. doi: 10.1590/s1413-70542007000400025

Suvarnakuta, P., Chaweerungrat, C., \& Devahastin, S. (2011). Effects of drying methods on the antioxidant activity of xanthones in mangosteen rind. Food Chemistry, 125(1), 240-247. doi: 10.1016/j. foodchem. 2010.09.015

Valadez-Carmona, L., Cortez-García, R. M., Plazola-Jacinto, C. P., NecoecheaMondragón, H., \& Ortiz-Moreno, A. (2016). Effect of microwave drying and oven drying on the water activity, color, phenolic compound content, and antioxidant activity of coconuthusk (Cocos nuciferaL.). Journal of Food Science and Technology, 53(9), 3495-3501. doi: 10.1007/s13197016-2324-7
Wojdyło, A., Figiel, A., Lech, K., Nowicka, P., \& Oszmiański, J. (2014). Effect of convective and vacuum-microwave drying on the bioactive compounds, color, and antioxidant capacity of Sour Cherries. Food and Bioprocess Technology, 7(3), 829-841. doi: 10.1007/s11947-013-1130-8

Zortéa-Guidolin, M. E. B., Carvalho, C. W. P. de, Godoy, R. C. B. de, Demiate, I. M., \& Scheer, A. P. (2017). Influence of extrusion cooking on in vitro digestibility and physical and sensory properties of Brazilian pine seed flour (Araucaria angustifolia). Journal of Food Science, 82(4), 977-984. doi: 10.11 11/1750-3841.13686 